\title{
Low neutral genetic diversity in isolated Greater Sage-Grouse (Centrocercus urophasianus) populations in northwest Wyoming
}

\author{
Sarah Schulwitz, ${ }^{1}$ Bryan Bedrosian, ${ }^{2}$ and Jeff A. Johnson ${ }^{1 *}$ \\ ${ }^{1}$ Department of Biological Sciences and Institute of Applied Sciences, University of North Texas, Denton, Texas \\ ${ }^{2}$ Craighead Beringia South, Kelly, Wyoming \\ * Corresponding author: jajohnson@unt.edu
}

Submitted March 26, 2014; Accepted July 25, 2014; Published October 15, 2014

\begin{abstract}
Identifying small, isolated populations is a conservation priority, not only because isolation may result in negative fitness consequences, but these populations may also harbor unique genetic diversity. The Greater Sage-Grouse (Centrocercus urophasianus) is a widespread obligate species of the sagebrush biome in western North America that has experienced range-wide contraction over the past century. To prevent local extirpation, efforts have been made to identify isolated populations. Here, we analyzed 16 microsatellite loci from 300 Greater Sage-Grouse individuals to assess genetic structure among populations in Wyoming and southeast Montana, particularly with the Jackson Hole and Gros Ventre populations in northwest Wyoming. Four genetic clusters were observed with Pinedale (central-west) and Casper (central) populations forming a cluster, Powder River Basin (central-north) and southeast Montana forming a second cluster, and both Jackson Hole and Gros Ventre forming distinct population clusters. All but the Jackson Hole and Gros Ventre genetic differentiation correspond with designated ecoregions and possessed an isolation-bydistance pattern of differentiation. Both Jackson Hole and Gros Ventre were identified as separate populations with asymmetrical dispersal into Gros Ventre. Both populations also possessed significantly reduced genetic diversity and low effective number of breeders $\left(N_{\mathrm{b}}\right)$. Because both populations are surrounded by extensive forested mountain ranges nearly devoid of sagebrush habitat, the Jackson Hole and Gros Ventre populations may have long been isolated from other Greater Sage-Grouse populations; however, only a few alleles were unique to the Jackson Hole and Gros Ventre populations. The observed genetic differentiation was largely due to allele frequency differences rather than private alleles, suggesting some historical gene flow. More work is needed to determine the timing of isolation and whether managers should focus on maintaining and increasing adequate sagebrush habitat, allowing the population to increase in size, or population supplementation to increase genetic diversity.
\end{abstract}

Keywords: connectivity, genetic diversity, microsatellite DNA, effective population size, Greater Sage-Grouse

Baja diversidad genética neutral en poblaciones aisladas de Centrocercus urophasianusen el noroeste de Wyoming

\section{RESUMEN}

La identificación de poblaciones pequeñas aisladas es una prioridad de conservación, no solo porque el asilamiento puede resultar en consecuencias negativas para la adecuación biológica, sino también porque estas poblaciones pueden albergar una diversidad genética única. Centrocercus urophasianus es una especie obligada ampliamente distribuida del bioma de Artemisa en el oeste de América del Norte que ha experimentado una contracción a lo largo de toda su área de distribución en el siglo pasado. Para prevenir la extirpación local, se han hecho esfuerzos para identificar las poblaciones aisladas. Aquí analizamos 16 loci microsatelitales de 300 individuos de C. urophasianus para evaluar la estructura genética entre poblaciones en Wyoming y el sudeste de Montana, particularmente en las poblaciones de Jackson Hole y Gros Ventre en el noroeste de Wyoming. Se observaron cuatro clústers genéticos, con las poblaciones de Pinedale (centro-oeste) y Casper (centro) formando un clúster, la Cuenca del Río Powder (centronorte) y sudeste de Montana formando un segundo clúster, y Jackson Hole y Gros Ventre formando clústers poblacionales distintos. Toda la diferenciación genética exceptuando a Jackson Hole y Gros Ventre se corresponde con las ecorregiones designadas y presenta un patrón de diferenciación de aislamiento-por-distancia. Jackson Hole y Gros Ventre fueron identificadas como poblaciones separadas con una dispersión asimétrica hacia Gros Ventre. Ambas poblaciones también presentaron una diversidad genética significativamente reducida y un bajo número efectivo de criadores $\left(N_{\mathrm{b}}\right)$. Debido a que ambas poblaciones están rodeadas por grandes cadenas montañosos con bosque casi desprovistas de hábitat de Artemisa, las poblaciones de Jackson Hole y Gros Ventre pueden haber estado aisladas por largo tiempo de otras poblaciones de C. urophasianus; sin embrago, solo unos pocos alelos fueron exclusivos de las poblaciones de Jackson Hole y Gros Ventre. La diferenciación genética observada se debió mayormente a las diferencias en la frecuencia de alelos más que a los alelos exclusivos, sugiriendo algún flujo génico histórico. Se 
necesita más trabajo para determinar el tiempo de aislamiento y si los gestores deberían enfocarse en mantener y aumentar el hábitat adecuado de Artemisa, permitiendo que las poblaciones aumenten en tamaño, o en suplementar a la población para aumentar la diversidad genética.

Palabras clave: Centrocercus urophasianus, conectividad, diversidad genética, microsatélites de ADN, tamaño poblacional efectivo

\section{INTRODUCTION}

Habitat degradation and fragmentation due to humanmediated activities are considered primary factors contributing to global biodiversity decline (Sala et al. 2000, Fahrig 2003, Baillie et al. 2004). As habitats are fragmented, populations become increasingly distant from each other, leading to reduced gene flow and loss of genetic diversity through drift (Reed 2004, Frankham 2005, Ezard and Travis 2006). This pattern is becoming increasingly pervasive throughout human-altered environments, with many species possessing isolated populations that may suffer fitness-related consequences (Westemeier et al. 1998, Blomqvist et al. 2010).

Sagebrush-steppe habitat in North America is one example where dramatic land-use changes over the past century have resulted in the isolation and decline of many sagebrush-dependent species (Knick et al. 2003, Rowland et al. 2011). The sagebrush biome (Artemesia spp.) was once a dominant habitat type across much of the northwestern United States but has recently been altered by anthropogenic activities including agriculture, livestock grazing, infrastructure development, invasive species (e.g., cheatgrass, Bromus tectorum), changes in fire regime, energy exploration, and oil and gas extraction (Knick and Connelly 2011).

Many of these impacts have a cumulative effect, resulting in sagebrush habitat fragmentation, degradation, and loss. Accordingly, animals considered sagebrush obligates, including Brewer's Sparrow (Spizella breweri), pygmy rabbit (Brachylagus idahoensis), and pronghorn (Antilocapra americana), have responded negatively to habitat alteration and fragmentation and are of increasing conservation concern (Baker et al. 1976, Knick and Rotenberry 2002, Rowland et al. 2006). For example, the pygmy rabbit has experienced a significant decline in population size and was listed as an Endangered Species in 2003 (USFWS 2003). Likewise, energy development activities have been shown to displace mule deer (Odocoileus hemionus), and there is increasing concern that removal and disruption of migration corridors may have negative impacts on their long-term population sustainability (Sawyer et al. 2005, 2006).

Another species of conservation concern in sagebrush habitat is the Greater Sage-Grouse (Centrocercus urophasianus). This species has experienced range-wide population contraction since European settlement of North America due to widespread sagebrush habitat alteration and loss (Schroeder et al. 2004, Knick and Connelly 2011). Greater Sage-Grouse now occupy $\sim 56 \%$ of their preEuropean settlement distribution, and populations are becoming increasingly isolated (Figure 1A; Schroeder et al. 2004, Oyler-McCance et al. 2005). In 2010 the U.S. Fish and Wildlife Service determined that Greater Sage-Grouse deserved protection under the Endangered Species Act, yet listing was precluded due to higher priority cases (see also Walker et al. 2007, Aldridge et al. 2008, Knick and Connelly 2011). A final decision concerning its listing is due by the end of fiscal year 2015 .

A concerted effort continues to identify areas that require conservation attention to prevent further Greater Sage-Grouse decline. Here, we focus on the Jackson Hole and Gros Ventre populations, both located in northwest Wyoming, in or near Grand Teton National Park (Figure 2). Despite habitat protection, both areas have experienced a reduction in census population size. Grand Teton National Park personnel, the Wyoming Game and Fish Department, and partners have monitored the Greater Sage-Grouse population in northwest Wyoming annually since 1986 (Upper Snake River Basin Sage-Grouse Working Group, USRBWG 2014). Annual lek counts have been conducted in northwest Wyoming at least 3 times per year, with leks visited every week during the breeding season (i.e. Apr-May) in the Jackson Hole valley. Average counts of males per lek declined from 35 between 1948 and 1951 (Patterson 1952) to 17 during the past 20 years (USRBWG 2014). Likewise, lek counts in Jackson Hole indicated 191-223 males per year before 1950 (Patterson 1952) but only 47-165 males per year over the past 20 years (USRBWG 2014). An estimated 2.2\% annual rate of population reduction occurred in the Jackson Hole area between 1985 and 2007 (Garton et al. 2011). The current Jackson Hole Greater Sage-Grouse population size is between 300 and 500 individuals primarily occupying $\sim 9,500$ ha of protected federal land (Grand Teton National Park and the National Elk Refuge; B. Bedrosian personal observation; see also Garton et al. 2011).

The Gros Ventre population is located $\sim 50 \mathrm{~km}$ to the east of Jackson Hole within Bridger-Teton National Forest. With the first lek located in 2000, the small population is thought to be restricted to breeding within $6.5 \mathrm{~km}$ of that lek site, but some grouse from this population extend their range up to $18 \mathrm{~km}$ to find adequate winter habitat (Bedrosian et al. 2010). The sagebrush habitat within the Gros Ventre River drainage is limited both to the north and south by large, 


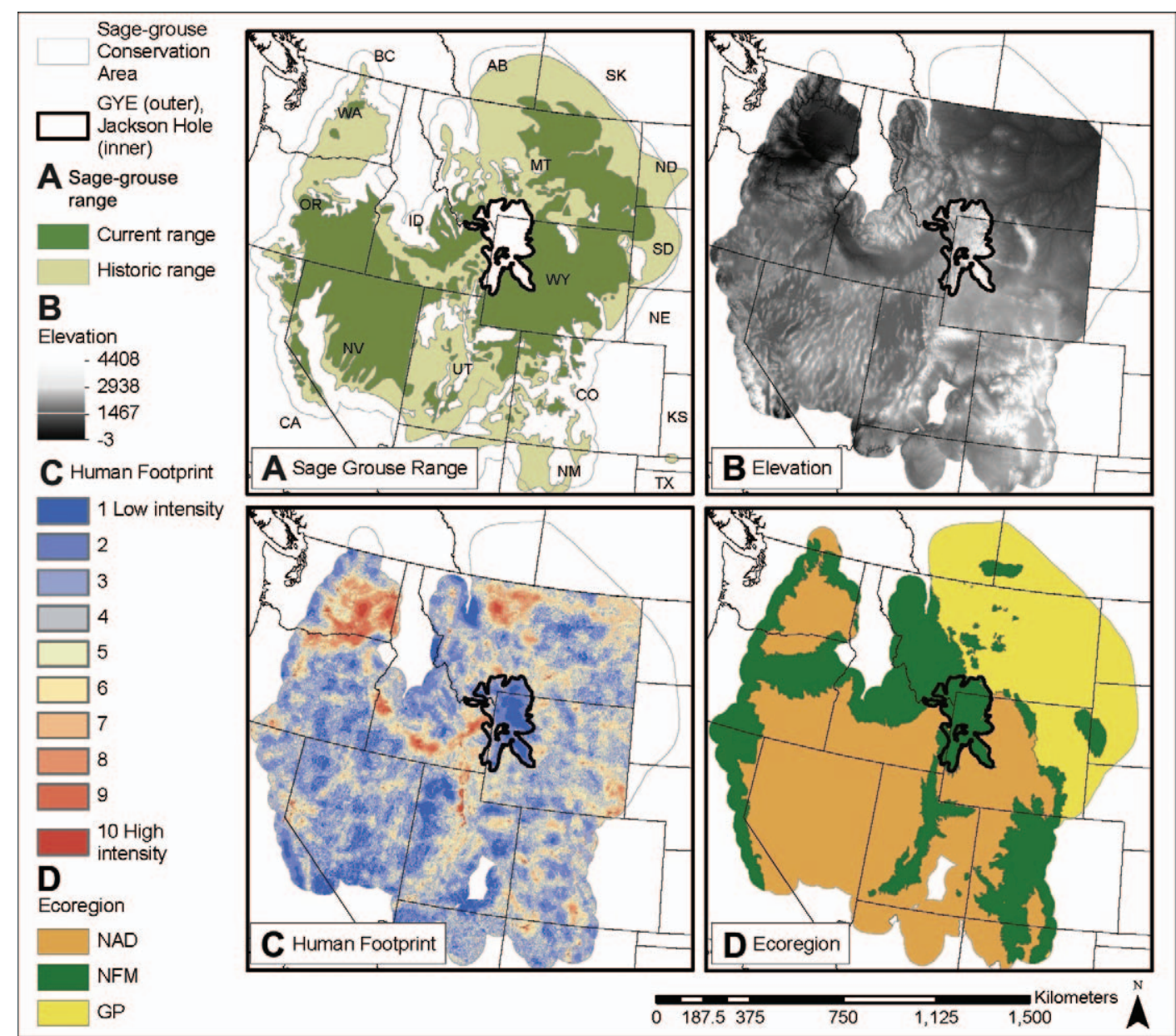

FIGURE 1. Greater Sage-Grouse conservation area (SGCA; Knick and Connelly 2011) with Greater Yellowstone Ecosystem (GYE) and the Jackson Hole study areas outlined in bold (adapted from Schroeder et al. 2004). (A) Historic and current sage-grouse distribution (adapted from Schroeder et al. 2004); (B) Elevation in the western United States (90 m DEM); (C) Human footprint intensity in the West (180 m; adapted from Leu et al. 2008); (D) North American level I Ecoregion delineations with North American Desert (NAD), Northwestern Forested Mountains (NFM), and Great Plains (GP; adapted from Commission for Environmental Cooperation Working Group 1997). GIS data for SGCA boundary and habitat layers for (A), (B), and (D) obtained from USGS SAGEMAP: A GIS Database for Sage-grouse and Shrubsteppe Management in the Intermountain West (http://sagemap.wr.usgs.gov/GISData.aspx). Base layer data for (C) obtained from USEPA (http://Figure 1B.epa.gov/wed/pages/ecoregions/na_eco.htm).

high-elevation mountain ranges. Although currently not known to occur, there is potential for connectivity with the Jackson Hole populations to the west and with the Pinedale population to the east by crossing $\sim 16 \mathrm{~km}$ of forested habitat. The objective of this study was to assess genetic structure and variation of the Greater Sage-Grouse populations in northwest Wyoming compared to larger populations in Wyoming and southeast Montana.

\section{METHODS}

\section{Tissue Collection and DNA Extraction}

Grouse were trapped on leks and geophagy sites using spotlight techniques (Giesen et al. 1982) and net launchers (Trapping Innovations, Kelly, WY, USA) during the spring each year over a 5-year period (2005-2009). Grouse were aged, sexed, outfitted with a VHF or GPS transmitter, and a blood sample was taken intravenously from the brachial vein of yearling and adult grouse. Blood samples were stored in lysis buffer (Longmire et al. 1988) or on FTA cards (Whatman, Clifton, NJ, USA) prior to DNA extraction. Both adults and juveniles from all locations were sampled, with the majority (70-100\%) being female. Grouse were sampled from 8 locations in Wyoming and 1 in southeastern Montana (Table 1; Figure 2). Samples were collected from Jackson Hole $(n=57)$ and Gros Ventre $(n=16$; Teton County) from 3 locations near Pinedale (Sublette County) designated North $(n=24)$, South $(n=28)$, and West $(n=$ 27) Pinedale; west of Casper ( $n=25$; Natrona County); and in Powder River Basin, east of Buffalo (Johnson County), 


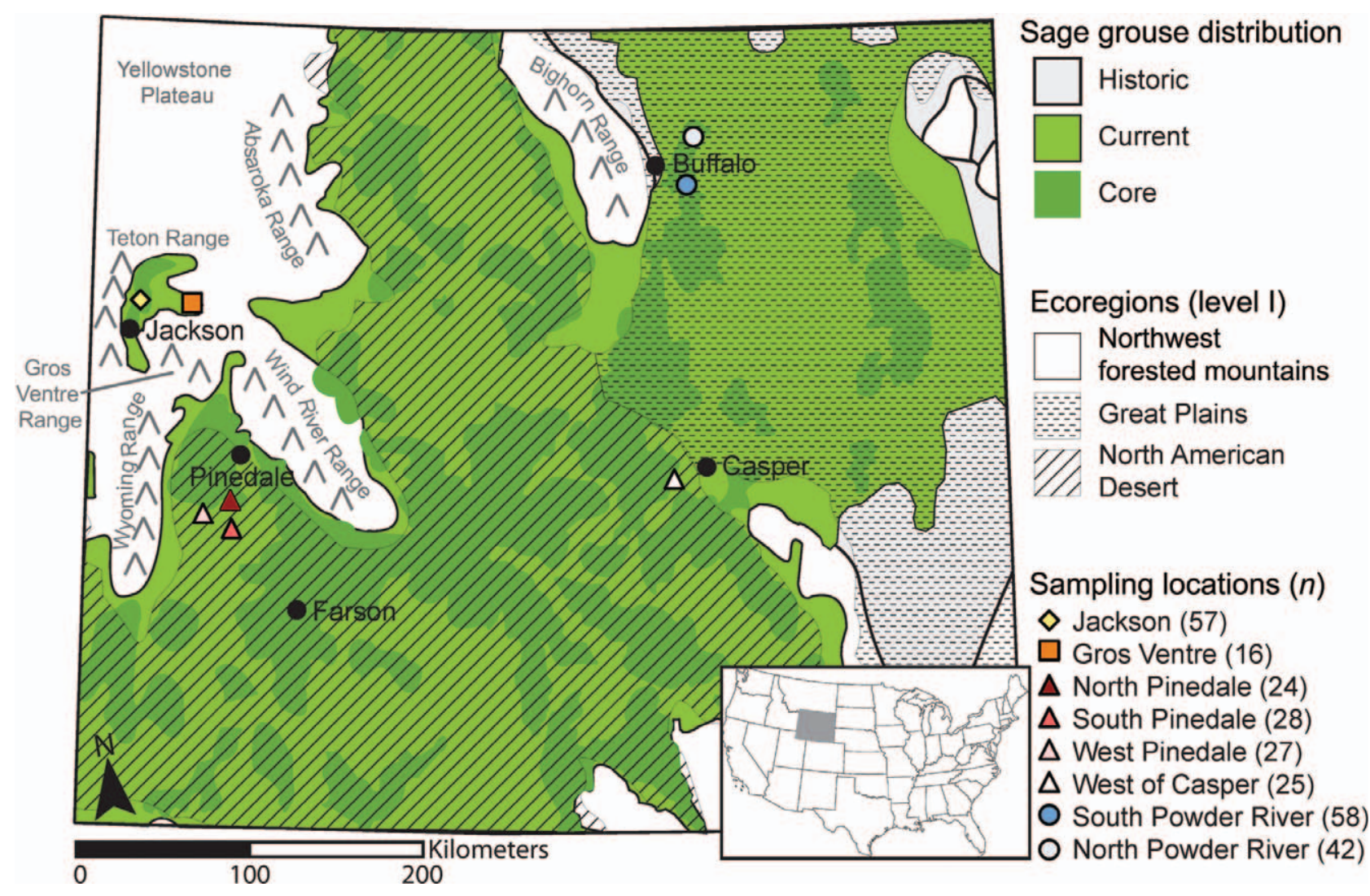

FIGURE 2. Approximate locations of Greater Sage-Grouse populations sampled in Wyoming. A population in southeast Montana was also sampled ( $n=23$; not shown on map, $200 \mathrm{~km}$ northeast of Buffalo, WY). Historic, current, and core Greater Sage-Grouse distributions are adapted from Schroeder et al. 2004 and from the Sage-Grouse Core Management Areas Version 3 Map (http:// wyofile.com/wp-content/uploads/2011/08/sg_coreareas.jpg). Level I ecoregions are adapted from Olson et al. 2001 and from ftp:// ftp.epa.gov/wed/ecoregions/cec_na/NA_LEVEL_I.pdf

designated North $(n=42)$ and South $(n=58)$ Powder River. Additional samples were collected in southeast Montana $(n$ =23; Carter County) and designated SE Montana. DNA was extracted from 300 samples using the DNeasy Blood and Tissue Kit following manufacturer's protocols (QIAGEN).

\section{Genotyping}

We chose 17 microsatellite loci based on previous Greater Sage-Grouse population genetic studies (Oyler-McCance et al. 2005, Bush et al. 2011). Microsatellite loci were originally developed for Greater Sage-Grouse (SGCA11.2,

TABLE 1. Measures of microsatellite genetic diversity (16 loci) for Greater Sage-Grouse sampling locations in Wyoming and southeast Montana: $n$, sample size; $A$, mean number of alleles; $A R$, allelic richness; $H_{\mathrm{o}}$, observed heterozygosity; $H_{\mathrm{e}}$, expected heterozygosity; $f$, inbreeding coefficient; $N_{\mathrm{b}}$, effective number of breeders. Letters as subscripts for $A R, H_{\mathrm{o}}$, and $H_{\mathrm{e}}$ indicate groups that are not significantly different $(\alpha=0.05)$.

\begin{tabular}{|c|c|c|c|c|c|c|c|}
\hline Locality & $n$ & $A$ & $A R$ & $H_{\mathrm{o}}$ & $H_{\mathrm{e}}$ & $f$ & $N_{\mathrm{b}}(95 \% \mathrm{Cl})^{* *}$ \\
\hline Jackson Hole & 57 & 7.0 & $6.1_{c}$ & $0.685_{b}$ & $0.732_{b c}$ & $0.065^{*}$ & $84(65-115)$ \\
\hline Gros Ventre & 16 & 5.5 & $5.5_{c}$ & $0.660_{b}$ & $0.695_{c}$ & 0.052 & $21(15-32)$ \\
\hline North Pinedale & 24 & 9.7 & $8.8_{\mathrm{ab}}$ & $0.794_{a}$ & $0.806_{a}$ & 0.015 & $919(504-4,265)$ \\
\hline South Pinedale & 28 & 11.2 & $9.4 \mathrm{a}$ & $0.779_{\mathrm{ab}}$ & $0.807 \mathrm{a}$ & 0.036 & \\
\hline West Pinedale & 27 & 10.5 & $9.1_{\mathrm{a}}$ & $0.794_{\mathrm{ab}}$ & $0.805_{a}^{a}$ & 0.013 & \\
\hline West of Casper & 25 & 9.8 & $8.5_{a b}$ & $0.780_{a}$ & $0.790_{a}$ & 0.013 & \\
\hline South Powder River & 24 & 9.6 & $7.7 \mathrm{~b}$ & $0.754 a b$ & $0.765_{\mathrm{ab}}$ & 0.014 & 194 (159-244) \\
\hline North Powder River & 58 & 9.6 & $7.6_{b}$ & $0.748_{a b}$ & $0.774_{a b}$ & $0.034^{*}$ & \\
\hline SE Montana & 23 & 8.9 & $8.1_{\mathrm{ab}}$ & $0.755_{\mathrm{ab}}$ & $0.779_{a}$ & 0.030 & \\
\hline
\end{tabular}

* inbreeding coefficient $(f)$ is significantly different from zero.

** $N_{\mathrm{b}}$ values are given for clusters identified by StRUCture (see Figure 3 ) 
Oyler-McCance et al. 2011; reSGCA5, reSGCA6, and reSGCA9, S. Oyler-McCance personal communication), Gunnison Sage-Grouse (Centrocercus minimus; SGMS06.4, SGMS06.6, SGMS06.8, MSP7, MSP11, MSP18, Oyler-McCance and St. John 2010), Eurasian Capercaillie (Tetrao urogallus; TUD3, TUT3, TUT4, Segelbacher et al. 2000), and Black Grouse (Tetrao tetrix; TTD6, Caizergues et al. 2001; BG6, BG14, Piertney and Höglund 2001; TTT3, Caizergues et al. 2003). SGMS06.6 was a trinucleotide repeat, and SGMS06.4, SGMS06.8, BG6, BG14, TUT3, TUT4, and TTT3 were tetranucleotide repeats; all remaining loci were dinucleotide repeats.

Polymerase chain reactions (PCR) were optimized and modified slightly from previously published methods that described protocols for each locus. A fluorescently labeled forward primer and an unlabeled reverse primer were used in PCRs. Each reaction was performed in $10 \mu \mathrm{L}$ final volume with final concentrations of $100 \mu \mathrm{M}$ each dNTP, $1 \times$ PCR buffer, and $0.1 \mu \mathrm{L}$ (0.5 units) GoTaq Flexi DNA polymerase (Promega). A final concentration of $1.0 \mathrm{mM}$ of each primer was used for SGMS06.4, SGMS06.8, MSP7, MSP18, and SGCA11.2 and $0.25 \mathrm{mM}$ for the remaining loci. $\mathrm{MgCl}_{2}$ concentrations ranged from $1.0 \mathrm{mM}$ (SGMS06.8) to $1.5 \mathrm{mM}$ (SGMS06.4, MSP7, MSP18, and SGCA11.2), and $2.25 \mathrm{mM}$ (remaining loci) per PCR reaction. Thermal profiles for all loci except TTD6 consisted of $2 \mathrm{~min}$ at $94^{\circ} \mathrm{C}, 35$ cycles of $30 \mathrm{~s}$ at $94^{\circ} \mathrm{C}, 30$ $\mathrm{s}$ at the specified annealing temperature described elsewhere (Segelbacher et al. 2000, Piertney and Höglund 2001, Oyler-McCance and St. John 2010, Oyler-McCance et al. 2011), with the exception of SGMS06.4, SGMS06.8, and TTT3 $\left(59.9^{\circ} \mathrm{C}, 55.4^{\circ} \mathrm{C}\right.$, and $58^{\circ} \mathrm{C}$, respectively), and 30 $\mathrm{s}$ at $72^{\circ} \mathrm{C}$, and a final $5 \mathrm{~min}$ extension at $72^{\circ} \mathrm{C}$. The thermal profile for TTD6 followed that described in Caizergues et al. (2001). Each amplified product was genotyped using an ABI 3130xl Genetic Analyzer and analyzed with the program GeneMarker v.1.6 (SoftGenetics).

\section{Statistical Analyses}

Genetic diversity. We tested microsatellite genotypes for linkage disequilibrium and departure from HardyWeinberg Equilibrium (HWE) within each population and locus using the program GDA v. 1.1 (Lewis and Zaykin 2001). Sequential Bonferroni corrections were used to correct for multiple simultaneous comparisons (Rice 1989). Mean number of alleles per locus $(A)$, observed $\left(H_{\mathrm{o}}\right)$ and expected $\left(H_{\mathrm{e}}\right)$ heterozygosity, and inbreeding coefficient $(f)$ were calculated using GDA, and allelic richness $(A R)$ was estimated using FSTAT v. 2.9.3.2 (Goudet 1995). AR provides an estimate of allelic diversity that controls for differences in samples sizes (Leberg 2002).

To assess genetic variability among sampling locations, we compared $A R, H_{\mathrm{o}}$, or $H_{\mathrm{e}}$ using a one-way analysis of variance (ANOVA) on ranked data, blocked by locus to control for interlocus variation $(\alpha=0.05$; SAS 9.3, SAS Institute, Cary, NC, USA). Significant findings were further analyzed using an a posteriori Student-Newman-Keuls multiple comparison test on ranked data to determine groups with means of ranks that did not significantly differ from each other. Values for $f$ were considered significant if their $95 \%$ confidence interval as calculated with GDA did not overlap with zero.

Population connectivity. Principal Coordinate Analysis (PCoA) was implemented in the Excel-based genetic analysis program GenAlEx v. 6.5 (Peakall and Smouse 2006). We used a PCoA to visualize the genetic relationships among individuals from each sample location based on genetic distance measures. The genetic distance (GD) matrix used in the PCoA was calculated using the Distance option (Peakall and Smouse 2006). One PCoA was conducted that included all populations. Two additional PCoAs were conducted a posteriori with subsets of the data to test for substructure (Figure 3).

To assess genetic differentiation between sampled populations, we calculated pairwise $F_{\mathrm{ST}}$ values following Weir and Cockerham (1984) as implemented in Arlequin v. 3.11 (Excoffier et al. 2005). Differences in population structure between sampling locations were tested using 1,000 permutations among populations with Fisher's exact test. In addition, we used the Bayesian method of Pritchard et al. (2000) as implemented in Structure v. 2.3.4 to identify the most likely number of genetic clusters $(K)$ among sampled individuals. This method identifies genetically distinct clusters based on maximizing HWE and linkage equilibrium among samples. Each simulation from $K=1$ to 10 was performed 20 times using a burn-in of 100,000 followed by 500,000 iterations while allowing for admixture, an individual $\alpha$ for each cluster, and a model of correlated allele frequencies that did not include prior information on population origin (see Falush et al. 2003). STRUCTURE was run to determine the most likely number of clusters for all populations. We performed additional STRUCTURE analyses to determine if further population structure existed within each of the initially identified clusters and used the web-based program STRUCTURE HARVESTER v. A.1 (Earl and vonHoldt 2012) and the Evanno $\Delta K$ method (Evanno et al. 2005) to determine the mostly likely number of genetically distinct clusters $(K)$. The program CLUMPP v. 1.1.2 (Jakobsson and Rosenberg 2007) was used to compile replicate run results from STRUCTURE, and the program DISTRUCT v. 1.1 was used to visualize results (Rosenberg 2004).

We evaluated correlations between genetic similarity (M) and geographic distances among populations (i.e. isolation by distance [IBD]) using the program Isolation By Distance Web Service v. 3.23 (IBDWS; Jensen et al. 2005). The program performs a Mantel test with pairwise 
A

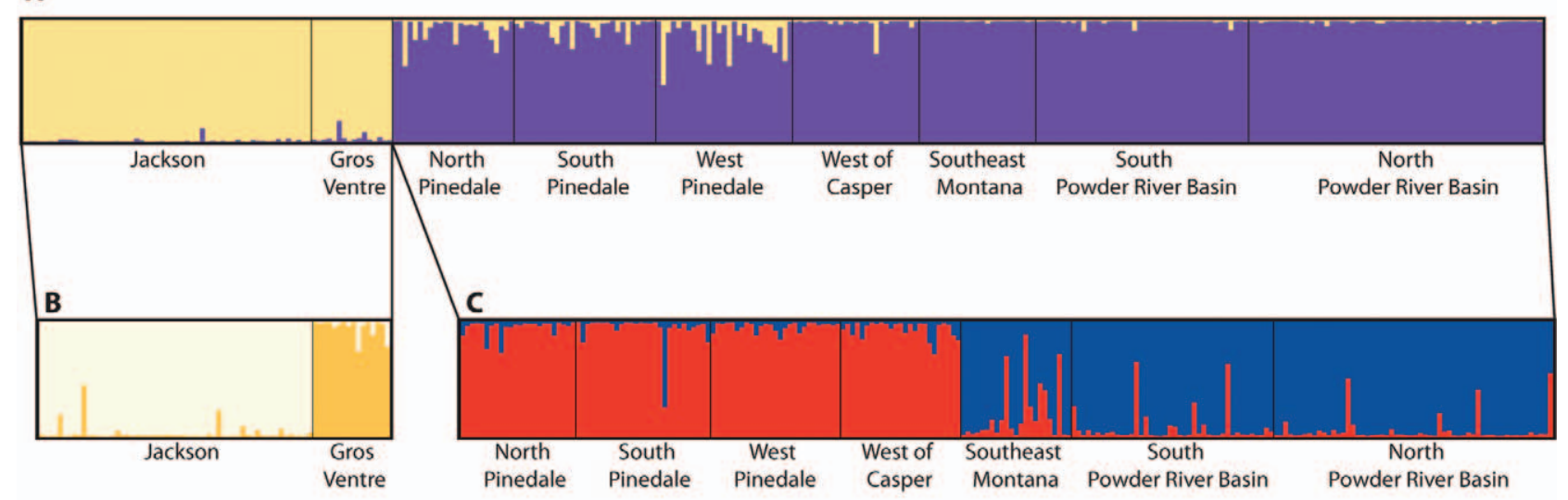

A2

B2

C2

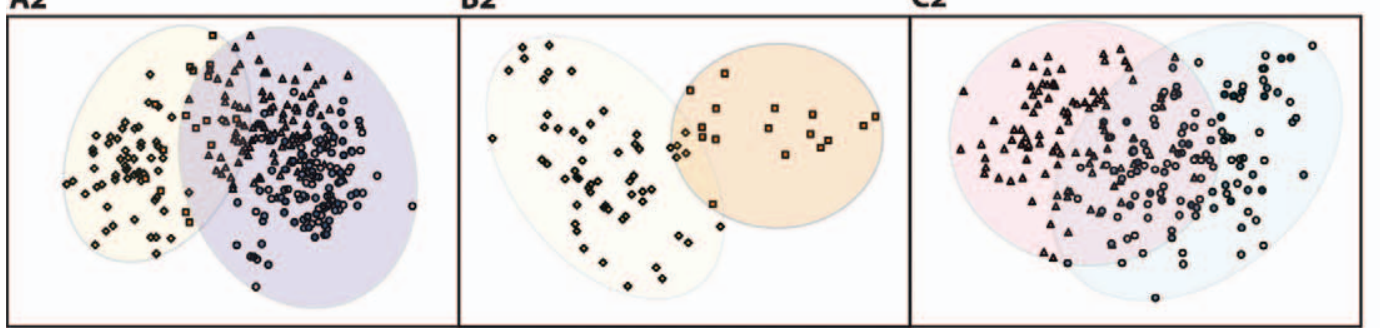

$\diamond$ Jackson

$\square$ Gros Ventre

$\Delta$ North Pinedale

$\Delta$ South Pinedale

$\Delta$ West Pinedale

$\triangle$ West of Casper

O Southeast Montana

O South Powder River

North Powder River

FIGURE 3. Bayesian clustering of Greater Sage-Grouse using StRUcture based on 16 microsatellite loci in (A) 8 sampling locations throughout Wyoming and 1 in Montana, (B) Jackson and Gros Ventre only, and (C) Pinedale, Casper, Powder River, and Montana sampling locations only. Each color represents a distinct cluster. Principal coordinate analysis (PCoA; A2, B2 and C2) corresponds to each of the sampling strategies used with Structure (A, B, and C, respectively).

matrices of geographic distance and Slatkin's (1993) measure of similarity, $\mathrm{M}=\left(1 / F_{\mathrm{ST}}-1\right) / 4$. Significance of IBD was tested with a Mantel procedure $(10,000$ permutations). Geographic distances between each population were measured using Google Earth.

To estimate the rates and direction of recent migration among populations, we used the Bayesian method for multilocus genotype data, BAYESAss v. 3.0.3 (Wilson and Rannala 2003). Because simulation studies show that the method's accuracy decreases with increased numbers of populations analyzed (Faubet et al. 2007), final analyses were conducted after combining sampling locations into 4 populations according to results obtained from STRUCTURE (see Results). Specifically, data for the Pinedale and Casper locations were clustered into a single population, data for the Powder River/Montana locations were clustered into a single population, and Jackson Hole and Gros Ventre were both included as independent populations. Mixing parameters were adjusted according to the user's manual to obtain acceptance rates between $20 \%$ and $60 \%$. Specifically, default delta values for migration rates were kept at 0.10 , while delta values for allele frequencies and inbreeding were 0.30 . The program was performed with a burn-in of $7.0 \times 10^{6}$ generations, $2.7 \times 10^{7}$ iterations, and sampling frequency of 1,000 . To ensure consistent estimates, we conducted 10 runs with different seed numbers. A rough 95\% credible set around the posterior mean was calculated using the provided mean and standard deviation according to the user's manual.

Effective number of breeders. We calculated estimates of effective number of breeders $\left(N_{\mathrm{b}}\right)$ based on the inbreeding effective size (Waples 2005, Waples and Do 2010) for each cluster identified with Structure (see Results) using the linkage disequilibrium method as implemented in LDNe v. 1.31 (Waples and Do 2008). Because sampled individuals included overlapping generations, population size estimates represent $N_{\mathrm{b}}$ rather than effective population size $\left(N_{\mathrm{e}}\right.$; Waples 2005, Waples and Do 2010). Alleles with frequencies $<0.02$ were excluded (Waples 2006), and 95\% confidence intervals for $N_{\mathrm{b}}$ were obtained using the jackknife option (Waples and Do 2008).

\section{RESULTS}

\section{Genetic Diversity Measures}

All loci were polymorphic with a range of 2 to 24 alleles per locus in each population. After adjusting for multiple comparisons, the majority of loci possessed no significant deviations from HWE or showed signs of linkage. Locus 
TABLE 2. Population pairwise $F_{\mathrm{ST}}$ comparisons based on 16 microsatellite loci. ${ }^{*} P<0.001$.

\begin{tabular}{|c|c|c|c|c|c|c|c|c|}
\hline & $\begin{array}{c}\text { Jackson } \\
\text { Hole }\end{array}$ & $\begin{array}{l}\text { Gros } \\
\text { Ventre }\end{array}$ & $\begin{array}{c}\text { North } \\
\text { Pinedale }\end{array}$ & $\begin{array}{c}\text { South } \\
\text { Pinedale }\end{array}$ & $\begin{array}{c}\text { West } \\
\text { Pinedale }\end{array}$ & $\begin{array}{l}\text { West of } \\
\text { Casper }\end{array}$ & $\begin{array}{l}\text { S Powder } \\
\text { River }\end{array}$ & $\begin{array}{l}\text { N Powder } \\
\text { River }\end{array}$ \\
\hline Gros Ventre & $0.088^{*}$ & - & & & & & & \\
\hline North Pinedale & $0.073^{*}$ & $0.084^{*}$ & - & & & & & \\
\hline South Pinedale & $0.084^{*}$ & $0.079^{*}$ & 0.004 & - & & & & \\
\hline West Pinedale & $0.070^{*}$ & $0.073^{*}$ & 0.007 & 0.006 & - & & & \\
\hline West of Casper & $0.093^{*}$ & $0.109^{*}$ & 0.009 & $0.021^{*}$ & $0.021^{*}$ & - & & \\
\hline S Powder River & $0.101^{*}$ & $0.104^{*}$ & $0.025^{*}$ & $0.034^{*}$ & $0.035^{*}$ & $0.035^{*}$ & - & \\
\hline N Powder River & $0.103^{*}$ & $0.103^{*}$ & $0.027^{*}$ & $0.039^{*}$ & $0.036^{*}$ & $0.030^{*}$ & $0.008^{*}$ & - \\
\hline SE Montana & $0.111^{*}$ & $0.107^{*}$ & $0.033^{*}$ & $0.037^{*}$ & $0.040^{*}$ & $0.046^{*}$ & $0.019^{*}$ & $0.023^{*}$ \\
\hline
\end{tabular}

TUD3, however, showed significant heterozygote deficiency in 4 populations (Jackson Hole, North Pinedale, West Pinedale, and Casper) and was excluded from all subsequent analyses.

Significant differences in $A R, H_{\mathrm{o}}$, and $H_{\mathrm{e}}$ were observed between sampled Greater Sage-Grouse populations (Table 1). Overall, the Pinedale and Casper populations exhibited the highest measures of neutral genetic diversity, SE Montana and each of the Powder River populations had intermediate levels, and Jackson Hole and Gros Ventre had the lowest diversity values. Significant inbreeding coefficients $(f)$ were observed for the Jackson Hole and North Powder River Basin populations, while all other populations were not significantly different from zero. There were 3 private alleles in Jackson Hole and 2 in Gros Ventre, whereas West, North, and South Pinedale had 1, 3, and 9 private alleles, respectively, Casper had 4, North and South Powder River both had 2, and SE Montana had 2 private alleles.

\section{Analyses of Population Structure}

Multiple methods indicated that Jackson Hole and Gros Ventre were isolated from all other sampled Greater SageGrouse populations. The PCoA showed limited differentiation among the majority of sampled Greater SageGrouse populations with the exception of the Jackson Hole population, which formed a separate distinct cluster, and to a lesser degree the Gros Ventre population, in which approximately half the individuals clustered with Jackson Hole, and the remaining clustered in an overlapping zone between Jackson Hole and the other sampled populations (Figure 3). When all populations were analyzed together, the first 3 coordinates accounted for $30.9 \%, 15.8 \%$, and $14.9 \%$ of the variation.

Pairwise $F_{\mathrm{ST}}$ values showed evidence of population differentiation among sampled locations with the highest values observed between comparisons with Jackson Hole (range 0.070-0.111) and also Gros Ventre (range 0.0730.109 ; Table 2). Pairwise $F_{\mathrm{ST}}$ values were significant $(\alpha=$ 0.001) for all populations except those between areas within Pinedale and between North Pinedale and the Casper population (Table 2).
Results from StRUCTURE also indicate that Jackson Hole and Gros Ventre were significantly differentiated from all other sampled locations, with $K=2$ as the most likely number of genetic clusters when all 9 sampling locations were analyzed as a single dataset (Figure 3; Appendix Figure 5). Specifically, Jackson Hole and Gros Ventre formed a single cluster, and individuals from the remaining sampling locations formed the second cluster. Within each cluster, further substructure was also observed, specifically between Jackson Hole and Gros Ventre $(K=2)$ and between Powder River Basin-Montana and PinedaleCasper ( $K=2$; Figure 3; Appendix Figure 5) when analyzed separately.

\section{Isolation-By-Distance Analyses}

Using microsatellite data from all sampled locations, a significant relationship was found between geographic distance $(\mathrm{km})$ and $\log$ genetic similarity $\left(r^{2}=0.175, P=\right.$ 0.025; Figure 4); however, all pairwise comparisons with Jackson Hole and Gros Ventre possessed relatively low levels of genetic similarity regardless of geographic distance (Figure 4; see also Table 2). This finding was further shown when Jackson Hole and Gros Ventre were excluded from the analysis, with the remaining sampled locations showing a stronger IBD relationship $\left(r^{2}=0.606\right.$, $P=0.001$; Figure 4).

\section{Contemporary Migration}

Based on estimates from BAYESAss, a high proportion of individuals were derived from their own populations $(>0.96)$ for all clusters except Gros Ventre (0.82; Table $3)$. Accordingly, recent immigration rates among the majority of the 4 clusters were low $(m<0.03)$ with the exception of Gros Ventre where a moderate portion of the individuals were identified as migrants derived from Jackson $(m=0.10)$, suggesting an asymmetric pattern of gene flow.

\section{Effective Number of Breeders}

Effective number of breeders varied among populations (Table 1). The Jackson and Gros Ventre population had small $N_{\mathrm{b}}$ (i.e. $<100$, upper $95 \%$ CI $<115$ individuals), the 


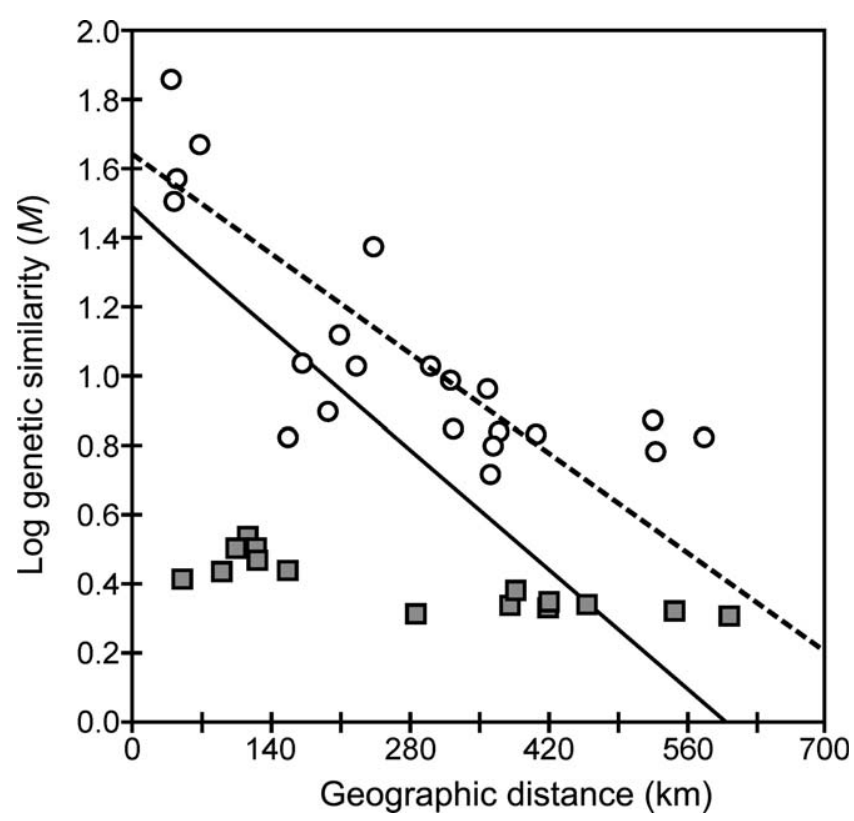

FIGURE 4. Analysis of isolation by distance (IBD) for microsatellite loci. Levels of log genetic similarity (M) are plotted against geographical distances $(\mathrm{km})$ for pairwise comparisons of all 9 sampled locations (solid line; $r^{2}=0.175, P=0.025$ ) and all locations except Jackson and Gros Ventre (dotted line; $r^{2}=$ $0.606, P=0.001$ ). Pairwise comparisons including Jackson and Gros Ventre are shown with gray squares. $P$-values represent significance of IBD using Mantel's test (10,000 permutations).

Powder River Basin-SE Montana populations had intermediate $N_{\mathrm{b}}$ (95\% CI 159-244 individuals), and the Pinedale-Casper population had relatively large $N_{\mathrm{b}}(95 \%$ CI 504-4,264 individuals).

\section{DISCUSSION}

Significant population genetic differentiation existed between Jackson Hole and sampled Greater Sage-Grouse populations in Wyoming and southeast Montana, including those in close geographic proximity to Jackson Hole (i.e. Pinedale and, to a lesser extent, Gros Ventre; Figure 3). Conversely, the remaining populations (i.e. excluding
Jackson Hole and Gros Ventre) seem to show an overall IBD pattern of population structure (Figure 4) similar to previous studies investigating Greater Sage-Grouse population connectivity using genetic methods (OylerMcCance et al. 2005, Bush et al. 2011). The number of private alleles in Jackson and Gros Ventre were not substantially different from other sampled populations of larger size, suggesting that the observed genetic differentiation observed with the Jackson Hole and Gros Ventre cluster is largely due to allele frequency differences and small population size (i.e. genetic drift) as opposed to unique alleles. A limited number of unique alleles may indicate more recent isolation as opposed to more historic long-term isolation.

Determining the timing of isolation has important implications for how the population should be managed. Both Jackson and Gros Ventre Greater Sage-Grouse populations possessed significantly reduced levels of neutral genetic diversity compared with the large core populations in Pinedale. Small and isolated populations are subject to exponential loss of genetic diversity over time through genetic drift at a rate that depends on their effective population size (Frankham 1996, Frankham et al. 2009). Therefore, because Jackson Hole and Gros Ventre Greater Sage-Grouse populations possess small $N_{\mathrm{b}}$, they are expected to lose more genetic diversity due to drift compared with larger populations over the same time period. Reduction in genetic diversity in small, isolated populations has been shown to negatively influence fitness due to increased inbreeding (Keller 1998, Daniels and Walters 2000, Blomqvist et al. 2010, Hammerly et al. 2013). In contrast, however, if the population has been small for hundreds of generations, deleterious traits may have been purged, and management should focus more on maintaining adequate habitat for long-term sustainability (e.g., Johnson et al. 2009) as opposed to introgression of genes that may result in outbreeding depression (Frankham et al. 2011). Although $F_{\mathrm{ST}}$ values for both Jackson Hole and Gros Ventre compared with the other sampled populations indicated moderate differentiation (i.e. $F_{\mathrm{ST}}=0.07-0.11$;

TABLE 3. Migration rates among Greater Sage-Grouse populations using the program BAYSEAss. Values shown are the means of the posterior distributions of $m$, the migration rate into each population, and their respective $95 \%$ credible set in parentheses. Values along the diagonal (in bold) are the population of individuals derived from the source population each generation. Migration rates $\geq 0.100$ are underlined. Populations are based on results from Structure (see Figure 3) with Pinedale-Casper and Powder River-SE Montana (MT) identified as separate populations.

Migration from:

\begin{tabular}{lcccc}
\cline { 2 - 5 } Migration into: & Jackson Hole & Gros Ventre & Pindale-Casper & Powder R-SE MT \\
\hline Jackson Hole & $\mathbf{0 . 9 8 3}(0.964-1.002)$ & $0.006(-0.006-0.018)$ & $0.006(-0.005-0.016)$ & $0.006(-0.005-0.016)$ \\
Gros Ventre & $\underline{0.100(0.002-0.198)}$ & $\mathbf{0 . 8 6 5}(0.763-0.966)$ & $0.018(-0.016-0.052)$ & $0.017(-0.015-0.049)$ \\
Pinedale-Casper & $0.006(-0.004-0.015)$ & $0.011(-0.005-0.027)$ & $\mathbf{0 . 9 6 3 ( 0 . 9 3 3 - 0 . 9 9 2 )}$ & $0.021(-0.004-0.046)$ \\
Powder R-SE MT & $0.003(-0.003-0.008)$ & $0.003(-0.003-0.009)$ & $0.006(-0.003-0.016)$ & $\mathbf{0 . 9 8 8}(0.976-1.000)$ \\
\hline
\end{tabular}


Frankham et al. 2009; Table 2), it is not known whether the differentiation is largely due to a recent reduction in population size and drift or represents a long-term pattern of isolation, with long-term isolation of more concern relative to outbreeding depression.

Multiple isolated populations have been identified in the Greater Sage-Grouse range based on genetic analyses (Oyler-McCance et al. 2005). The Douglas-Grant and Yakima populations in Washington are small and isolated in a geographic region that has been more recently used for agriculture (Oyler-McCance et al. 2005), suggesting a more recent pattern of isolation. In contrast, North Park, Middle Park, and Eagle populations are in high-elevation valleys in Colorado and are genetically distinct from nearby, but more widespread, Wyoming Basin populations (Oyler-McCance et al. 2005). This pattern suggests that long-standing landscape features, such as mountains and high elevation sagebrush habitat, may have been an important factor leading to the genetic differentiation of these populations. Likewise, Gunnison Sage-Grouse are not only geographically isolated from Greater Sage-Grouse populations, they are also morphologically different in body size and plumage (Hupp and Braun 1991, Young et al. 2000). These examples suggest that multiple factors over a broad temporal period have contributed to sage-grouse population differentiation.

Long-term landscape features such as mountain ranges have likely influenced the demographic history of Greater Sage-Grouse in northwest Wyoming. Jackson Hole and Gros Ventre are surrounded by high elevation conifer forest, including multiple mountain ranges (i.e. Teton, Wyoming, Wind River, and Gros Ventre ranges; Figures 1 and 2) that most likely limit Greater Sage-Grouse dispersal (Hupp and Braun 1991, Musil et al. 1993, Reese and Connelly 1997, Garton et al. 2011). Due to these high elevation and large forested tract barriers, the most likely dispersal route from Jackson Hole goes to the east and south toward the Pinedale population (Figure 2); however, the Euclidian distance between the 2 populations exceeded the interseasonal movement and dispersal of Greater SageGrouse reported in Wyoming (Holloran and Anderson 2004, Bedrosian et al. 2010, Fedy et al. 2012) further supporting the differentiation we found with population genetics.

Furthermore, the Jackson Hole and Gros Ventre populations have greater snowfall, higher elevation, and more limited habitat (i.e. Figure 1B and D) compared with the other areas sampled for this study. If sufficient time has passed following isolation, habitat differences may result in local adaptation (Kawecki and Ebert 2004, Caro et al. 2009) and reproductive isolation (i.e. ecological speciation; Schluter 2009, Nosil 2012). The genetic differentiation observed with Structure (Figure 3) corresponds to the level I ecoregion delineation for the State of Wyoming (Commission for Environmental Cooperation Working Group 1997, Olson et al. 2001; Figure 1D). If ecological differences are sufficient, local adaptation may further limit contemporary gene flow, eventually resulting in separate species, similar to Gunnison Sage-Grouse (Young et al. 2000) and Red Crossbill (Loxia curvirostra complex; Benkman 2003, Smith and Benkman 2007, Smith et al. 2012).

Chong et al. (2011) suggested that due to limited habitat, wintering Greater Sage-Grouse in Jackson Hole may utilize nontraditional habitats, such as exposed hillsides or tall deciduous shrublands, as compared with other Greater Sage-Grouse populations. More widespread sampling within and among each ecoregion targeting multiple populations on opposite sides of ecotones (i.e. area of transition) is required to adequately test whether habitat differences as designated by ecoregion is sufficient to limit gene flow among Greater Sage-Grouse populations (see also Smith et al. 1997, Porlier et al. 2009). Interestingly, the genetic data indicated that contemporary asymmetric gene flow existed between Gros Ventre, possibly acting as a sink, and Jackson Hole ( $10 \%$ immigration rate) and Pinedale ( $\sim 2 \%$ immigration rate) as independent source populations with no gene flow occurring in opposite directions (Table 3). While it is not known whether Greater SageGrouse use the Gros Ventre River Drainage system for dispersal, other species such as pronghorn that also breed in Grand Teton National Park migrate south each year using that corridor (Sawyer et al. 2005). Because of the higher immigration rate, these results do suggest that maintaining connectivity between the Gros Ventre and Jackson Hole populations is supported, and that the 2 areas should be managed as subpopulations (e.g., Waples and Gaggiotti 2006).

To what degree recent changes in the landscape near Jackson Hole and surrounding areas have influenced Greater Sage-Grouse population structure in northwest Wyoming is not known, but human-mediated reduction of sagebrush habitat in the surrounding area (i.e. Pinedale) may have contributed to the isolation we detected and to isolation of other species in the area. For example, a large annual elk migration that once extended through Jackson Hole to southwest Wyoming during the fall and winter months was obstructed and ceased by the end of the $19^{\text {th }}$ century. Wintering elk are now restricted to an area designated as the National Elk Refuge, located north of the town of Jackson (Cromley 2000). Habitat in the valley continued to decline throughout the $20^{\text {th }}$ century. In the 1950s, 9,425 ha of sagebrush habitat was available for Greater Sage-Grouse in the southern portion of Jackson Hole, or roughly $19 \%$ less than pre-settlement estimates of 11,579 ha. Currently, only 6,674 ha of sagebrush habitat exists in this area, supporting a Greater Sage-Grouse 
population of roughly half that observed in the 1950s (Bedrosian et al. 2010).

While Greater Sage-Grouse habitat in both Jackson Hole and Gros Ventre is largely protected from expanding urbanization, agriculture, and energy development, risk still exists from fire, park infrastructure development, and climate change (USRBWG 2014). Among immediate threats, 1 of Jackson Hole's 9 active Greater Sage-Grouse leks is located at the end of the Jackson Hole Airport (JAC) runway, which is the only commercial airport located entirely within a U.S. national park. From 1993 to 2012, strikes involving at least 36 Greater Sage-Grouse at JAC were reported to the Federal Aviation Administration, with 9 of these occurring in 2010 (http://wildlife.faa.gov/ database.aspx; Mead and Hunt Inc. 2012). In addition to direct mortality, courtship behavior and brood rearing in the vicinity of the airport may be affected by the chronic intermittent noise produced by the $\sim 40$ flights per day (Blickley et al. 2012; http://www.jacksonholeairport.com/). In a population with small $N_{\mathrm{b}}$, Greater Sage-Grouse mortality at the JAC airport may represent an important factor limiting population growth. Consequently, the Jackson Hole Airport is currently preparing a Wildlife Hazard Management Plan in cooperation with Grand Teton National Park to help mitigate impacts on the population.

In addition to immediate threats, the potential impact of future climate change presents a long-term threat to Greater Sage-Grouse in the region (USRBWG 2014). The greatest temperature changes in Wyoming during the past 50 years have occurred in the high-elevation areas (i.e. northwest Wyoming; USRBWG 2014). Thus, potential climate change impacts, such as long-term drought or more severe winter snowstorms, may be of particular concern to the Jackson Hole and Gros Ventre populations (USRBWG 2014). Such risks may be compounded in these populations by their relatively limited access to sagebrush habitat and isolation from surrounding populations with larger expanses of habitat, such as those to the south in the Wyoming Basin (USRBWG 2014). To buffer against the potential negative impacts of future climate change, management should prioritize restoration and maintenance efforts that promote sagebrush habitat diversity and resilience (USRBWG 2014).

In 1948-1949, 359 Greater Sage-Grouse (269 adults and 90 juveniles) were translocated into the Jackson Hole valley from Eden Valley, Wyoming (Sweetwater County; Patterson 1952), $35 \mathrm{~km}$ south of the south Pinedale area sampled in this study. Following the release, band resighting estimates from 1950 and 1951 suggested that 9.5-11\% of males on leks were translocated individuals (Patterson 1952). Patterson suggested that few adults established in relocated areas, whereas released juveniles were more likely to establish in the second season following their release. No systematic surveys were conducted to estimate breeding by translocated females $(n=95)$ or copulations by translocated males. Our results suggest that either the released birds did not enter the effective breeding population or that the strength of genetic drift was sufficient to change the allele frequencies of the Jackson Hole population relative to other populations within the past 60 years (e.g., Johnson et al. 2004, Landguth et al. 2010).

Given the degree of genetic differentiation between the Jackson Hole area and the surrounding regions, it is also possible that the Jackson Hole population has developed morphological or behavioral differences relative to their environment that resulted in the released birds being precluded from breeding, as has happened with the divergence of plumage and vocalizations in Gunnison Sage-Grouse from Greater Sage-Grouse (Young et al. 1994, see also Johnson and Dunn 2006). More data are needed to elucidate any differences in appearance, sound, or strutting behavior between populations or whether environmental differences among Greater Sage-Grouse populations may limit introgression following translocation (i.e. outbreeding depression).

\section{Conservation Implications and Future Considerations} Identifying isolated populations of Greater Sage-Grouse is a conservation priority given the extent of recent land use changes throughout the species' distribution (e.g., Channell and Lomolino 2000, Nielsen et al. 2001, Willi et al. 2006, Peterman et al. 2013). This study identified the Greater Sage-Grouse populations in Jackson Hole and Gros Ventre as genetically isolated with reduced neutral genetic diversity compared to nearby populations in Wyoming and southeast Montana. We were unable to obtain tissue samples from Greater Sage-Grouse populations in Idaho; however, the distance between populations in Jackson Hole and eastern Idaho are beyond the dispersal distance documented for Greater Sage-Grouse based on radiotelemetry (Fedy et al. 2012), and the Teton Range eastern slope rises sharply from its base to $\sim 2 \mathrm{~km}$ above Jackson Hole (Figure 1). Future studies should include eastern Idaho to investigate whether connectivity exists between the 2 areas.

Because Jackson Hole and Gros Ventre Greater SageGrouse populations are small, additional loss in genetic diversity due to drift is likely. Management priority should focus on preventing further reduction in current population size in an effort to minimize any further loss of genetic diversity in these 2 populations. While the present study identified both Jackson Hole and Gros Ventre populations as isolated with asymmetric dispersal between the 2 populations, it is not known if the current pattern was due to recent human-mediated changes to the landscape or more historic processes. Further work is currently 
under way to determine the timing of isolation among Greater Sage-Grouse populations, including the Jackson Hole and Gros Ventre populations.

The final decision date on whether to list the Greater Sage-Grouse under the Endangered Species Act is approaching. Core Greater Sage-Grouse habitat extends across much of central and western Wyoming; however, this is also the location of existing and potentially future oil and gas extraction areas. As such, policymakers who seek to better mitigate the negative impacts of habitat alteration on Greater Sage-Grouse populations should consider the findings of this and similar studies to better address ways to reverse population decline.

\section{ACKNOWLEDGMENTS}

This study was made possible due to collaborations with multiple individuals and organizations. We thank Matt Holloran, Rusty Kaiser, Tom Maechtle, Cheryl Mandich, and Melissa Foster for providing samples. Sara OylerMcCance provided guidance on the choice of microsatellite loci. We are grateful to Derek Craighead, Rusty Kaiser, Susan Wolff, Steve Cain, and Eric Cole for logistical support. We thank the many field technicians that helped gather samples from all field studies. This manuscript was greatly improved with the comments of the Journal editors and reviewers. Funding was provided by the Bureau of Land Management, Craighead Beringia South, Wyoming Game and Fish Department, Grand Teton National Park, the Jackson Hole Airport, UW-NPS Research Station, Community Foundation of Jackson Hole, Bridger-Teton National Forest, Big Horn Environmental Consultants, and private foundations and individuals.

\section{LITERATURE CITED}

Aldridge, C. L., S. E. Nielsen, H. L. Beyer, M. C. Boyce, J. W. Connelly, and S. T. Knick (2008). Range-wide patterns of greater sage-grouse persistence. Diversity and Distributions 14:983-994.

Baillie, J. E. M., C. Hilton-Taylor, and S. N. Stuart (Editors) (2004). 2004 IUCN red list of threatened species. A global species assessment. International Union for Conservation of Nature, Gland, Switzerland, and Cambridge, UK.

Baker, M. F., R. L. Eng, J. S. Gashwiler, M. H. Schroeder, and C. E. Braun (1976). Conservation committee report on effects of alteration of sagebrush communities on the associated avifauna. Wilson Bulletin 88:165-171.

Bedrosian, B., R. Crandall, and D. Craighead (2010). Jackson Hole sage-grouse project completion report: 2007-2009. Unpublished Report. Craighead Beringia South. http:// beringiasouth.org/Websites/beringiasouth/images/Grouse_ Report_Final.pdf

Benkman, C. W. (2003). Divergent selection causes the adaptive radiation of crossbills. Evolution 57:1176-1181.

Blickley, J. L., D. Blackwood, and G. L. Patricelli (2012). Experimental evidence for the effects of chronic anthropo- genic noise on abundance of greater sage-grouse at leks. Conservation Biology 26:461-471.

Blomqvist, D., A. Pauliny, M. Larsson, and L. A. Flodin (2010). Trapped in the extinction vortex? Strong genetic effects in a declining vertebrate population. BMC Evolutionary Biology 10:33.

Bush, K., C. Dyte, B. Moynahan, C. Aldridge, H. Sauls, A. Battazzo, B. Walker, K. Doherty, J. Tack, J. Carlson, D. Eslinger, et al. (2011). Population structure and genetic diversity of Greater Sage-Grouse (Centrocercus urophasianus) in fragmented landscapes at the northern edge of their range. Conservation Genetics 12:527-542.

Caizergues, A., S. Dubois, A. Loiseau, G. Mondor, and J. Y. Rasplus (2001). Isolation and characterization of microsatellite loci in Black Grouse (Tetrao tetrix). Molecular Ecology Notes 1:36-38.

Caizergues, A., O. Rätti, P. Helle, L. Rotelli, L. Ellison, and J. Y. Rasplus (2003). Population genetic structure of male black grouse (Tetrao tetrix L.) in fragmented vs. continuous landscapes. Molecular Ecology 12:2297-2305.

Caro, S. P., A. Charmantier, M. M. Lambrechts, J. Blondel, J. Balthazart, and T. D. Williams (2009). Local adaptation of timing of reproduction: Females are in the driver's seat. Functional Ecology 23:172-179.

Channell, R., and M. V. Lomolino (2000). Dynamic biogeography and conservation of endangered species. Nature 403: 84-86.

Chong, G., W. Wetzel, and M. Holloran (2011). Research reports: Greater Sage-Grouse of Grand Teton National Park: Where do they roam. Park Science 27:36-43.

Commission for Environmental Cooperation Working Group. (1997). Ecological regions of North America-Toward a common perspective: Montreal, Commission for Environmental Cooperation. $71 \mathrm{p}$.

Cromley, C. M. (2000). Historical elk migrations around Jackson Hole, Wyoming. Yale School of Forestry and Environmental Studies Bulletin 104:53-65.

Daniels, S. J., and J. R. Walters (2000). Inbreeding depression and its effects on natal dispersal in red-cockaded woodpeckers. The Condor 102:482-491.

Earl, D. A., and B. M. vonHoldt (2012). StructureHarvester: A website and program for visualizing StRUCtURE output and implementing the Evanno method. Conservation Genetics Resources 4:359-361.

Evanno, G., S. Regnaut, and J. Goudet (2005). Detecting the number of clusters of individuals using the software StRUCTURE: A simulation study. Molecular Ecology 14:2611-2620.

Excoffier, L., G. Laval, and S. Schneider (2005). Arlequin (version 3.0): An integrated software package for population genetics data analysis. Evolutionary Bioinformatics Online 1:47.

Ezard, T. H. G., and J. M. J. Travis (2006). The impact of habitat loss and fragmentation on genetic drift and fixation time. Oikos 114:367-375.

Fahrig, L. (2003). Effects of habitat fragmentation on biodiversity. Annual Review of Ecology, Evolution, and Systematics 34: 487-515.

Falush, D., M. Stephens, and J. K. Pritchard (2003). Inference of population structure using multilocus genotype data: Linked 
loci and correlated allele frequencies. Genetics 1641:5671587.

Faubet, P., R. S. Waples, and O. E. Gaggiotti (2007). Evaluating the performance of a multilocus Bayesian method for the estimation of migration rates. Molecular Ecology 16:11491166.

Fedy, B., C. Aldridge, K. Doherty, M. O'Donnell, J. Beck, B. Bedrosian, M. Holloran, G. Johnson, N. Kaczor, C. Kirol, C. Mandich, et al. (2012). Interseasonal movements of greater sage-grouse, migratory behavior, and an assessment of the core regions concept in Wyoming. Journal of Wildlife Management 76:1062-1071.

Frankham, R. (1996). Relationship of genetic variation to population size in wildlife. Conservation Biology 10:15001508.

Frankham, R. (2005). Genetics and extinction. Biological Conservation 126:131-140.

Frankham, R., J. Ballou, and D. Briscoe (2009). Introduction to Conservation Genetics. New York, NY.

Frankham, R., J. D. Ballou, M. D. Eldridge, R. C. Lacy, K. Ralls, M. R. Dudash, and C. B. Fenster (2011). Predicting the probability of outbreeding depression. Conservation Biology 25:465-475.

Garton, E. O., J. W. Connelley, J. S. Horne, C. A. Hagen, A. Moser, and M. A. Schroeder (2011). Greater Sage-Grouse dynamics and probability of persistence. In: Greater Sage-Grouse: Ecology and Conservation of a Landscape Species and its Habitats (S. T. Knick and J. W. Connelly, Editors). Studies in Avian Biology 38. Berkeley, CA. pp. 293-381.

Giesen, K. M., T. J. Schoenberg, and C. E. Braun (1982). Methods for trapping sage grouse in Colorado. Wildlife Society Bulletin 10:224-231.

Goudet, J. (1995). FSAT (version 1.2): A computer program to calculate F-statistics. Journal of Heredity 86:485-486.

Hammerly, S. C., M. E. Morrow, and J. A. Johnson (2013). A comparison of pedigree- and DNA-based measures for identifying inbreeding depression in the critically endangered Attwater's Prairie-Chicken. Molecular Ecology 22:53135328.

Holloran, M. J., and S. J. Anderson (2004). Greater Sage-Grouse seasonal habitat selection and survival in Jackson Hole, Wyoming. Research Completion Report. University of Wyoming Cooperative Fish and Wildlife Research Unit, Laramie, WY.

Hupp, J. W., and C. E. Braun (1991). Geographic variation among sage grouse in Colorado. Wilson Bulletin 103:255-261.

Jakobsson, M., and N. A. Rosenberg (2007). CLUMPP: A cluster matching and permutation program for dealing with label switching and multimodality in analysis of population structure. Bioinformatics 23:1801-1806.

Jensen, J. L., A. J. Bohonak, and S. T. Kelley (2005). Isolation by distance, web service. BMC Genetics 6:13. v.3.23 http://ibdws. sdsu.edu/

Johnson, J. A., M. R. Bellinger, J. E. Toepfer, and P. Dunn (2004). Temporal changes in allele frequencies and low effective population size in Greater Prairie-Chickens. Molecular Ecology $13: 2617-2630$.

Johnson, J. A., and P. O. Dunn (2006). Low genetic variation in the heath hen prior to extinction and implications for the conservation of prairie-chicken populations. Conservation Genetics 7:37-48.

Johnson, J. A., R. E. Tingay, M. Culver, F. Hailer, M. Clarke, and D. Mindell (2009). Long-term survival despite low genetic diversity in the critically endangered Madagascar Fish-Eagle. Molecular Ecology 18:54-63.

Keller, L. F. (1998). Inbreeding and its fitness effects in an insular population of song sparrows (Melospiza melodia). Evolution 52:240-250.

Kawecki, T. J., and D. Ebert (2004). Conceptual issues in local adaptation. Ecology Letters 7:1225-1241.

Knick, S. T., and W. Connelly (2011). Greater Sage-Grouse and sagebrush: An introduction to the landscape. In: Greater SageGrouse: Ecology and Conservation of a Landscape Species and its Habitats (S. T. Knick and J. W. Connelly, Editors). Studies in Avian Biology no. 38. Berkeley, CA. pp. 1-9.

Knick, S. T., D. S. Dobkin, J. T. Rotenberry, M. A. Schroeder, W. M. Vander Haegen, and C. van Riper III (2003). Teetering on the edge or too late? Conservation and research issues for avifauna of sagebrush habitats. The Condor 105:611634.

Knick, S. T., and J. T. Rotenberry (2002). Effects of habitat fragmentation on passerine birds breeding in intermountain shrubsteppe. Studies in Avian Biology 25:130-140.

Landguth, E. L., S. A. Cushman, M. K. Schwartz, K. S. McKelvey, M. Murphy, and G. Luikart (2010). Quantifying the lag time to detect barriers in landscape genetics. Molecular Ecology 19: 4179-4191.

Leberg, P. L. (2002). Estimating allelic richness: Effects of sample size and bottlenecks. Molecular Ecology 11:2445-2449.

Lewis, P. O., and D. Zaykin (2001). Genetic data analysis: Computer program for the analysis of allelic data, version 1.0 (d16c). Free program distributed by the authors over the Internet. http://lewis.eeb.uconn.edu/lewishome/software. html

Leu, M., S. E. Hanser, and S. T. Knick (2008). The human footprint in the West: A large-scale analysis of anthropogenic impacts. Ecological Applications 18(5):1119-1139.

Longmire, J. L., A. W. Lewis, N. C. Brown, J. M. Clark, M. D. Jones, L. J. Meinke, J. Meyne, R.L. Ratcliff, F. A. Ray, R. P. Wagner, and R. K. Moyzis (1988) Isolation and molecular characterization of a highly polymorphic centromeric tandem repeat in the family Falconidae. Genomic 2:14-24.

Mead and Hunt, Inc. (2012) Jackson Hole Airport Wildlife Hazard Management Plan Information Packet. Santa Rosa, CA. http:// www.jacksonholeairport.com/perch/resources/jac-whmppacket-113012final-pdf.pdf

Musil, D. D., J. W. Connelly, and K. P. Reese (1993). Movements, survival, and reproduction of sage grouse translocated into central Idaho. Journal of Wildlife Management 57:85-91.

Nielsen, J. L., J. M. Scott, and J. L. Aycrigg (2001). Endangered species and peripheral populations: Cause for conservation (letter to the Editor). Endangered Species Update 18:194197.

Nosil, P. (2012). Ecological Speciation. New York, NY.

Olson, D. M., E. Dinerstein, E. D. Wikramanayake, N. D. Burgess, G. V. N. Powell, E. C. Underwood, J. A. D'amico, I. Itoua, H. E. 
Strand, J. C. Morrison, C. J. Loucks, et al. (2001). Terrestrial ecoregions of the World: A new map of life on Earth. BioScience 51:933-938.

Oyler-McCance, S. J., and J. St. John (2010). Characterization of small microsatellite loci for use in noninvasive sampling studies of Gunnison Sage-Grouse (Centrocercus minimus). Conservation Genetics Resources 2:17-20.

Oyler-McCance, S. J., C. A. Stricker, J. St. John, C. E. Braun, G. T. Wann, M. S. O'Donnell, and C. L. Aldridge (2011). Effects of climate change on nutrition and genetics of White-tailed Ptarmigan. In: Ecology, Conservation, and Management of Grouse (B.K. Sandercock, K. Martin, and G. Segelbacher, Editors). Studies in Avian Biology no. 39. Berkeley, CA. pp. 283-294.

Oyler-McCance, S., S. Taylor, and T. Quinn (2005). A multilocus population genetic survey of the greater sage-grouse across their range. Molecular Ecology 14:1293-1310.

Patterson, R. L. (1952). The Sage Grouse in Wyoming. Wyoming Game and Fish Commission. Sage Books, Denver, CO.

Peakall, R., and P. E. Smouse (2006). GenAlEx 6: Genetic analysis in Excel. Population genetic software for teaching and research. Molecular Ecology Notes 6:288-295.

Peterman, W. E., S. M. Feist, R. D. Semlitsch, and L. S. Eggert (2013). Conservation and management of peripheral populations: Spatial and temporal influences on the genetic structure of wood frog (Rana sylvatica) populations. Biological Conservation 158:351-358.

Piertney, S. B., and J. Höglund (2001). Polymorphic microsatellite DNA markers in Black Grouse (Tetrao tetrix). Molecular Ecology Notes 1:303-304.

Porlier, M., M. Bélisle, and D. Garant (2009). Non-random distribution of individual genetic diversity along an environmental gradient. Philosophical Transactions of the Royal Society B: Biological Sciences 364:1543-1554.

Pritchard, J. K., M. Stephens, and P. Donnelly (2000). Inference of population structure using multilocus genotype data. Genetics 155:945-959.

Reed, D. H. (2004). Extinction risk in fragmented habitats. Animal Conservation 7:181-191.

Reese, K. P., and J. W. Connelly (1997). Translocations of Sage Grouse Centrocercus urophasianus in North America. Wildlife Biology 3:235-241.

Rice, W. R. (1989). Analyzing tables of statistical tests. Evolution 43:223-225.

Rosenberg, N. A. (2004). DISTRUCT: A program for the graphical display of population structure. Molecular Ecology Notes 4: 137-138.

Rowland, M. M., L. H. Suring, M. Leu, S. T. Knick, and M. J. Wisdom (2011). Sagebrush-associated species of conservation concern. In: Sagebrush Ecosystem Conservation and Management: Ecoregional Assessment Tools and Models for the Wyoming Basins (S. E. Hanser, M. Leu, S. T. Knick, and C. L. Aldridge, Editors). Lawrence, KS. pp. 46-68.

Rowland, M. M., M. J. Wisdom, L. H. Suring, and C. W. Meinke (2006). Greater Sage-Grouse as an umbrella species for sagebrush-associated vertebrates. Biological Conservation 129:323-335.

Sala, O. E., F. S. Chapin III, J. J. Armesto, E. Berlow, J. Bloomfield, R. Dirzo, E. Huber-Sanwald, L. F. Huenneke, R. B. Jackson, A.
Kinzig, R. Leemans, et al. (2000). Global biodiversity scenarios for the year 2100. Science 287:1770-1774.

Sawyer, H., F. Lindzey, and D. McWhirter (2005). Mule deer and pronghorn migration in western Wyoming. Wildlife Society Bulletin 33:1266-1273.

Sawyer, H., R. M. Nielson, F. Lindzey, and L. L. McDonald. (2006). Winter habitat selection of mule deer before and during development of a natural gas field. Journal of Wildlife Management 70:396-403.

Schroeder, M. A., C. L. Aldridge, A. D. Apa, J. R. Bohne, C. E. Braun, S. D. Bunnell, J. W. Connelly, P. A. Deibert, S. C. Gardner, M. A. Hilliard, G. D. Kobriger, et al. (2004). Distribution of sagegrouse in North America. The Condor 106:363-376.

Schluter, D. (2009). Evidence for ecological speciation and its alternative. Science 323:737-741.

Segelbacher, G., R. J. Paxton, G. Steinbrück, P. Trontelj, and I. Storch (2000). Characterization of microsatellites in capercaillie Tetrao urogallus (AVES). Molecular Ecology 9:19191952.

Slatkin, M. (1993). Isolation by distance in equilibrium and nonequilibrium populations. Evolution 47:264-279.

Smith, J. W., and C. W. Benkman (2007). A coevolutionary arms race causes ecological speciation in crossbills. The American Naturalist 169:455-465.

Smith, J. W., S. M. Sjoberg, M. C. Mueller, and C. W. Benkman (2012). Assortative flocking in crossbills and implications for ecological speciation. Proceedings of the Royal Society B 279: 4223-4229.

Smith, T. B., R. K. Wayne, D. J. Girman, and M. W. Bruford (1997). A role for ecotones in generating rainforest biodiversity. Science 276:1855-1857.

Upper Snake River Basin Sage-grouse Local Working Group (USRBWG). (2014). Upper Snake River Basin Sage-grouse Conservation Plan. http://wgfd.wyo.gov/wtest/Departments/ Wildlife/pdfs/SG_USRCONSERVATIONPLAN0000685.pdf

U.S. Fish and Wildlife Service (USFWS) (2003). Endangered and threatened wildlife and plants: Final rule to list the Columbia Basin distinct population segment of the pygmy rabbit (Brachylagus idahoensis) as endangered. Federal Register 68: 10388-10409.

Walker, B. L., D. E. Naugle, and K. E. Doherty (2007). Greater Sage-Grouse population response to energy development and habitat loss. Journal of Wildlife Management 71:26442654.

Waples, R. S. (2005). Genetic estimates of contemporary effective population size: To what time periods do the estimates apply? Publications, Agencies and Staff of the U.S. Department of Commerce. Paper 462.

Waples, R. S. (2006). A bias correction for estimates of effective population size based on linkage disequilibrium at unlinked gene loci. Conservation Genetics 7:167-184.

Waples, R. S., and C. Do (2008). LDNE: A program for estimating effective population size from data on linkage disequilibrium. Molecular Ecology Resources 8:753-756.

Waples, R. S., and C. Do (2010). Linkage disequilibrium estimates of contemporary Ne using highly variable genetic markers: A largely untapped resource for applied conservation and evolution. Evolutionary Applications 3:244-262. 
Waples, R. S., and O. Gaggiotti (2006). What is a population? An empirical evaluation of some genetic methods for identifying the number of gene pools and their degree of connectivity. Molecular Ecology 15:1419-1439.

Weir, B. S., and C. C. Cockerham (1984). Estimating F-Statistics for the analysis of population structure. Evolution 38:13581370.

Westemeier, R. L., J. D. Brawn, S. A. Simpson, T. L. Esker, R. W. Jansen, J. W. Walk, E. L. Kershner, J. L. Bouzat, and K. N. Paige (1998). Tracking the long-term decline and recovery of an isolated population. Science 282:1695-1698.

Willi, Y., J. Van Buskirk, and A. A. Hoffmann (2006). Limits to the adaptive potential of small populations. Annual Review of Ecology, Evolution, and Systematics 37:433-458.
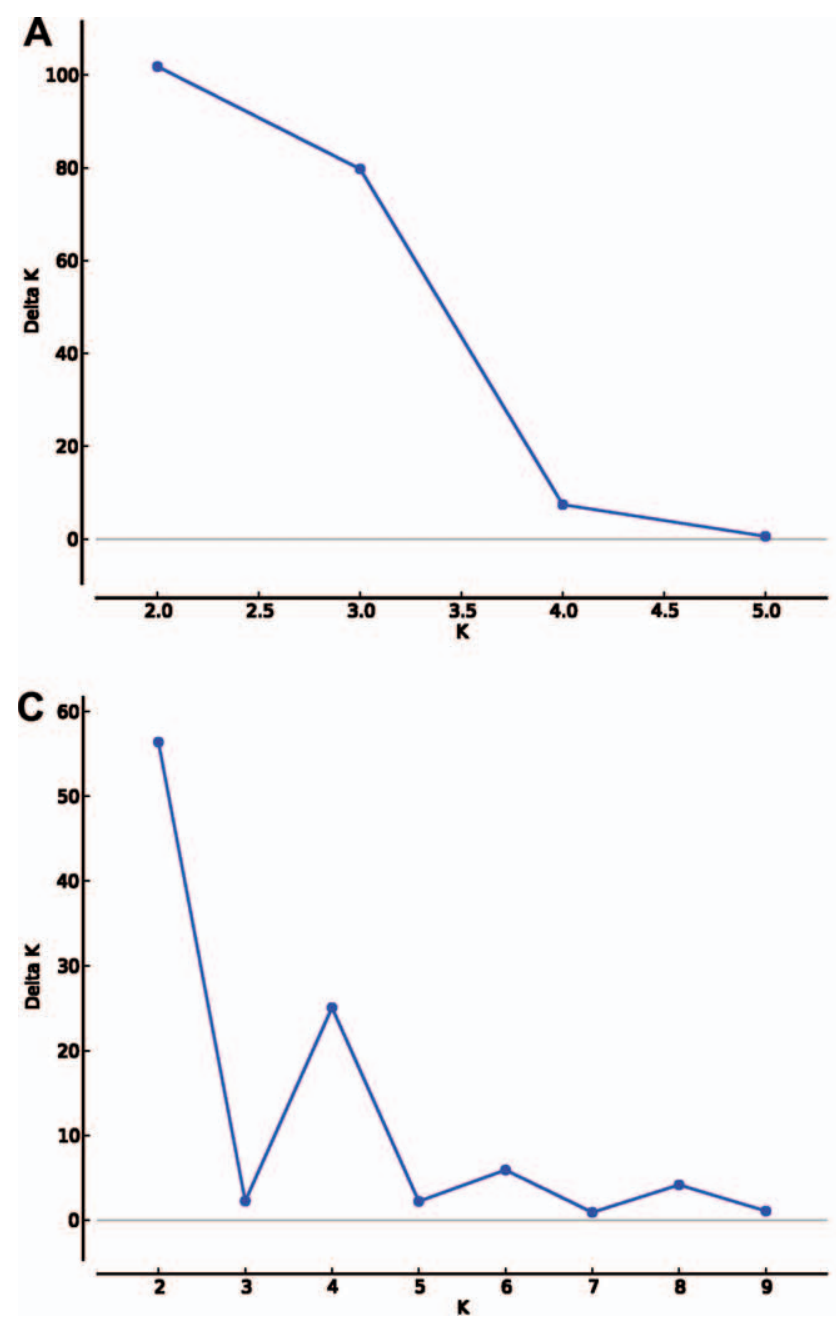

Wilson, G. A., and B. Rannala (2003). Bayesian inference of recent migration rates using multilocus genotypes. Genetics 163: 1177-1191.

Young, J. R., C. E. Braun, S. J. Oyler-McCance, J. W. Hupp, and T. W. Quinn (2000). A new species of sage-grouse (Phasianidae: Centrocercus) from southwestern Colorado. Wilson Bulletin 112:445-453.

Young, J. R., J. W. Hupp, J. W. Bradbury, and C. E. Braun (1994). Phenotypic divergence of secondary sexual traits among sage grouse Centrocercus urophasianus populations. Animal Behavior 47:1353-1362.

\section{APPENDIX}

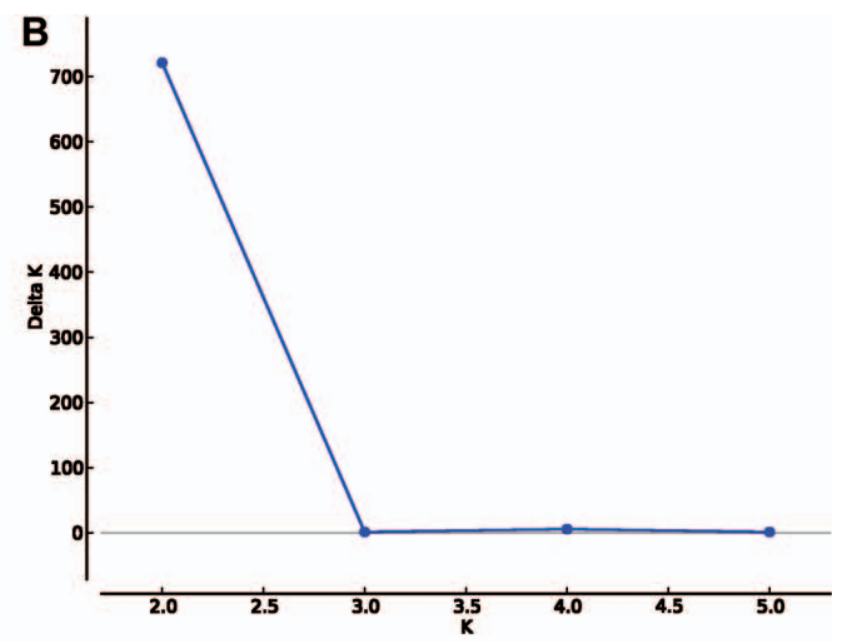

APPENDIX FIGURE 5. Evanno plots derived from STRUCTURE HARVESTER separating (A) Jackson/Gros Ventre Greater Sage-grouse from other sampling locations in Wyoming. Analysis with datasets reduced to the two initially defined clusters showed further substructure with (B) Jackson and Gros Ventre grouse separating into two clusters and (C) Pinedale/Casper and Powder River Basin/ Montana grouse separating into two clusters. 